\title{
Acetylcholine receptor antibody as a diagnostic test for myasthenia gravis: results in 153 validated cases and 2967 diagnostic assays
}

\author{
Angela Vincent
}

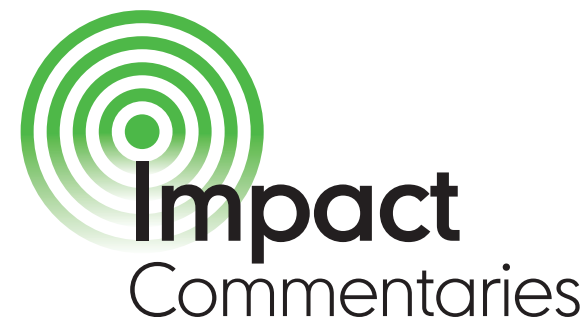

Clinical neuroimmunology, particularly the detection of autoantibodies in neurological diseases, has come a long way since 1985. There are now many immunotherapy responsive peripheral and central neurological diseases that can be diagnosed by serological tests. Commercial assays are being developed to enable wider and faster diagnostic testing in the future

In 1976, Jon Lindstrom, who had already shown in 1973 that rabbits immunised against acetylcholine receptors (AChRs) developed an experimental form of myasthenia gravis (MG), published the first systematic study of $\mathrm{AChR}$ antibodies in $M \mathrm{MG}^{2}$ The antibody assay was based on immunoprecipitation by patients' IgG antibodies of detergent solubilised muscle AChRs (obtained mainly from amputated limb muscle) that had been labelled with radioactive bungarotoxin, a snake toxin that binds irreversibly to AChRs. It was a neat method and is still in use today. In 1976, I was working at University College London with Ricardo Miledi (now 'retired' but still experimenting at UCSD), mainly measuring AChR antibodies and muscle AChRs in animals that we had immunised against AChRs purified from Torpedo electric organs by one of Ricardo's postdocs, chemist David Green (now Professor of Genetics at Otago University). We had already started to collaborate with John Newsom-Davis (who died tragically in

Correspondence to Professor A Vincent, Nuffield Department of Clinical Neurosciences, University of Oxford, John Radcliffe Hospital, Oxford OX3 9DU, UK angela.vincent@clneuro.ox.ac.uk
ACETYLCHOLINE RECEPTOR ANTIBODY AS A DIAGNOSTIC TEST FOR MYASTHENIA GRAVIS: RESULTS IN 153 VALIDATED CASES AND 2967 DIAGNOSTIC ASSAYS

Authors: A Vincent, J Newsom-Davis Year published: 1985

a road traffic accident in 2007), a neurologist at the National Hospital in Queen Square, London, to measure AChRs in MG muscles, so I set up the antibody assay for use with patients' serum. John and I began to perform the test for routine diagnosis in the UK and to look extensively at levels during and after plasma exchange, which John had just shown with Tony Pinching and (later Sir) Keith Peters to be highly effective clinically in the patients. ${ }^{3}$

The paper in JNNP, published 9 years later, described the distribution of AChR antibody levels in the first 2967 samples; this seemed a lot at the time but there are now well over 10000 AChR antibody assays performed each year just in the UK! Comparing the results from validated cases with those sent for diagnosis, we argued that even rather marginal ('equivocal') AChR antibody levels were useful diagnostically since similar levels were found in $3 \%$ of John's 153 validated patients. We showed that some AChR antibodies at high concentration can displace the radioactive bungarotoxin, leading to an underestimate of their titre-or even a negative result-but that this could be circumvented by performing the assay at two serum concentrations and by using lower amounts of the toxin so that not all of the bungarotoxin binding sites were occupied. We stressed the importance of using normal (adult AChR) as well as the much higher levels of denervated (fetal AChR) muscle (obtained rather gruesomely from amputated limbs collected in large black plastic bags from all over London) as a source of the AChRs since some sera reacted preferentially with adult AChR. And we demonstrated that some patients become 'seropositive' over time so should be retested if negative initially. But most importantly, we showed the existence of a distinct seronegative MG (SNMG) group (also pointed out by Lindstrom $^{2}$ ). For these patients, we offered some possible explanations for the negative results, including the existence of antibodies to other target(s) or that their antibodies did not bind to detergent extracted AChRs.

In fact, the 'SNMG' patients were an enigma for many years; some of them were a little different clinically with more bulbar involvement and little or no response to thymectomy, but others were less severely affected. Importantly, all responded to plasma exchange and visiting clinical fellow Stuart Mossman (now consultant neurologist back in Wellington, New Zealand) purified their IgG and transferred evidence of neuromuscular transmission failure to mice. ${ }^{4}$ Eventually, other antigens were identified; muscle specific kinase $(\mathrm{MuSK})^{5}$ in a variable proportion and recently another neuromuscular junction protein, LRP4, ${ }^{6}$ so far in a very few. Moreover, we find that some antibodies that do not immunoprecipitate AChRs or MuSK from solution can be detected binding to native adult AChRs when they are expressed and clustered on the surface of transfected cells at a high density, similar to that at the neuromuscular junction; these clustered AChR antibodies are found in patients who have thymic pathology and clinical features similar to those with typical AChR-MG.' This 'cell based' approach is also more sensitive for detecting MuSK antibodies.

Meanwhile, the radioimmunoprecipitation concept continued to prove useful, and had unforeseen consequences; antibodies to voltage gated calcium channels and voltage gated potassium channels (VGKC) were measured in Lambert Eaton 
myasthenic syndrome and acquired neuromyotonia, respectively, using solubilised brain tissue and specific neurotoxins (see Buckley and Vincent ${ }^{8}$ ), and the detection of VGKC antibodies led to the identification of non-paraneoplastic and immunotherapy responsive patients with limbic encephalitis or Morvans' syndrome. This was fortunate because it turns out that most of the antibodies are, in fact, directed at other proteins (mainly LGI1 and CASPR2 so far) that are complexed with the VGKCs in solubilised brain tissue; antibodies binding to these proteins co-precipitate the radioactively labelled VGKCs (see Vincent and colleagues $^{9}$ ). Antibodies to LGI1, CASPR2 and other recently identified targets such as NMDAR, AMPAR, GABABbRs, GlyRs and AOP4 are all now measured using the cell based approach, in a widening variety of CNS diseases, very often non-paraneoplastic, and immunotherapy responsive. ${ }^{8}$ Moreover, commercial assays using fixed cells expressing different antigens or
ELISAs are being established for use in routine laboratories, offering the potential for faster analysis and wider diagnosis of these conditions in the future. The field has expanded considerably, but it was the radioimmunoprecipitation assay that began to convince neurologists back in the 1970s that there were antibody mediated neurological diseases, and it should be given credit for helping to identify these new disorders and putting neuroimmunology squarely on the neurological map.

Competing interests None.

Provenance and peer review Commissioned; not externally peer reviewed.

Received 26 July 2011

Accepted 15 August 2011

J Neurol Neurosurg Psychiatry 2012;83:237-238.

doi:10.1136/jnnp-2011-301046

\section{REFERENCES}

1. Vincent A, Newsom-Davis J. Acetylcholine receptor antibody as a diagnostic test for myasthenia gravis: results in 153 validated cases and 2967 diagnostic assays. J Neurol Neurosurg Psychiatry 1985;48:1246-52

2. Lindstrom JM, Seybold ME, Lennon VA, et al. Antibody to acetylcholine receptor in myasthenia gravis. Prevalence, clinical correlates, and diagnostic value. Neurology 1976;26:1054-9

3. Pinching AJ, Peters DK, Davis JN. Plasma exchange in myasthenia gravis. Lancet 1977;1:428-9.

4. Mossman S, Vincent A, Newsom-Davis J. Myasthenia gravis without acetylcholine-receptor antibody: a distinct disease entity. Lancet 1986;1:116-19

5. Hoch W, McConville J, Helms S, et al. Autoantibodies to the receptor tyrosine kinase MuSK in patients with myasthenia gravis without acetylcholine receptor antibodies. Nat Med 2001;7:365-8.

6. Higuchi 0, Hamuro J, Motomura M, et al. Autoantibodies to low-density lipoprotein receptorrelated protein 4 in myasthenia gravis. Ann Neurol 2011;69:418-22.

7. Leite MI, Jacob S, Viegas S, et al. IgG1 antibodies to acetylcholine receptors in 'seronegative' myasthenia gravis. Brain 2008;131:1940-52.

8. Buckley C, Vincent A. Autoimmune channelopathies Nat Clin Pract Neurol 2005;1:22-33.

9. Vincent A, Bien CG, Irani SR, et al. Autoantibodies associated with diseases of the CNS: new developments and future challenges. Lancet Neurol 2011; 10:759-72. 